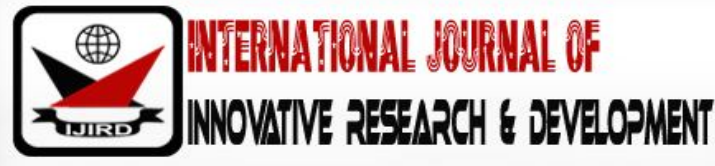

ISSN 2278 - 0211 (Online)

\section{Strategies for Curbing Examination Malpractice in Higher Institutions in Rivers State, Nigeria}

Dr. Chikwe, C. K.
Senior Lecturer, Department of Educational Psychology, Guidance and Counselling,
Ignatius Ajuru University of Education, Rumuolumeni, Port Harcourt, Nigeria
Dr. Ogidi, R.C.
Senior Lecturer, Department of Educational Psychology, Guidance and Counselling,
Ignatius Ajuru University of Education, Rumuolumeni, Port Harcourt, Nigeria

\begin{abstract}
This study investigated strategies for curbing examination malpractice in Higher Institutions in Rivers State. The study adopted descriptive research design. Four research questions and four hypotheses were formulated to guide the study. An instrument designed by the researchers titled "Strategies for Curbing Examination Malpractice in Higher Institutions (SCEMHI)" was used in collecting data for the study. Mean score was used in answering the research questions while independent t-test was used in testing the hypotheses at 0.05 level of significance. The result of the study showed that: strategies for curbing examination malpractice in higher institutions in Rivers State does not significantly differ based on gender, the length of service, rank, and faculty. This shows that efforts put into curbing examination malpractice in higher institutions are beginning to yield fruit, this will improve the standard of education at that level.
\end{abstract}

Keywords: Examination, examination malpractice, strategies, students, lecturers

\section{Introduction}

Examination is one of the measures for determining the knowledge, ability, competencies, and skills acquired by a learner or an individual after the process of teaching and learning. Examination is so important that it is used in certification, promotion, employment and selection into institutions or for any other purposes. It is in the light of the above that examination is taken by pupils in primary schools, students in secondary schools and students in higher institutions of learning. Hence, every effort is been made to pass an examination at all cost. Pupils, students, candidate, and applicants employ every means at their disposal to pass examination not minding the consequences. The craze to pass an examination, by all means, has led many students, especially in higher institutions to engage in examination malpractice.

Examination malpractice has been defined by experts in education, psychology and other fields of human endeavour. Asuru (2004) defined examination malpractice as bad practice applied in an examination in order to make the examinee earn an unmerited grade. Asuru further explained that examination malpractice is an illegal act by the examinee or examiner or his/ her agent(s) before, during or after the examination with the intent to make the examinee have an undue advantage or earn an unmerited grade. Section 19 of Act 33, 1999 (Examination Malpractices Act, 1999) in Asuru (2004) defined examination malpractice as an act, which constitutes an offense under the Decree (Act). Such acts include cheating at an examination, stealing of question papers, disorderliness, obstruction, forgery, breach of duty, conspiracy, aiding, abetting and impersonation. To Igwe (1990), examination malpractice is the practice by which prospective candidates for an examination illegally gain access to the examination paper in advance of the date of the examination. Also, Wokocha and Ukujagu in Wali (2007) described examination malpractice as an evil or improper practice applied by examinee in order to be declared successful in the examination. Jessica Ezekiel-Hart (2006) opined that in more simple terms, examination malpractice is the violation of the rules governing the conduct of an examination by somebody in an official position. Ezekiel-Hart further observed that examination rules can be violated by teachers, clerks, secretaries, examination supervisors, and students, all of whom occupy official positions in the school system. Examination malpractice, therefore, is an illegal act engaged or employed by examinees, supervisors, custodians of question papers and all those participating in the conduct of an examination, to assist an examinee or group of examinees have undue advantage over others in obtaining higher grades. Examination malpractice seems to be the order of the day in schools especially in higher institutions of learning. Examination malpractice can take place before, during and after examination. 
A lot of factors have been adduced as the causes of examination malpractice. Arugungu, Tukor and Musa in JessicaHark (2006) identified the following as causes of examination malpractice; poor teaching methods, poor timing of lesson, the inability of students to cope with school work, high student-teacher ratio, congested sitting arrangements, too much emphasis on paper qualification, greed, and materialism. Wali (2007) has identified fear of failure in examination, the need to get rich quick, inadequate motivation of teachers, lack of teaching facilities, the need to enhance the status of the school, an overcrowded sitting arrangement in the examination hall, and the need to meet parents' expectation. Others include students' lack of self-confidence, peer/ group influence, etc.

The consequences or effects of examination malpractice cannot be overemphasized. They include generation of false information, wrong orientation, poor academic performance, increased level of anti-social behavior. Anzene (2014) has identified consequences of examination malpractice as, dismissal, termination, loss of position and self-confidence, irreversible loss of credibility, production of doctors who will forget scissors and towel in the stomach after operation and production, and indiscriminate sales of fake drugs by pharmacists and massive fraud in commercial banks. Examination malpractice has produced fake engineers, doctors, lawyers, businessmen and women and teachers who are at the various tiers of government. Even most lecturers in the higher institutions in the country earned their degrees through examination malpractice and as a result, have increased the rate of sorting, sexual harassment and other vices in our school system. Examination malpractice has resulted in a high level of corrupt practices in the society. The judicial legislative and executive arms are all occupied by persons who acquired their qualifications through examination malpractice. Other institutions and strata of the society have been impacted negatively by this "monster" called examination malpractice.

Examination malpractice takes various forms, and among them are; leakage of examination papers in advance of actual date of the examination, smuggling or bringing unauthorized materials into the examination hall in any manner or form, attempt to copy or actually copying from fellow students or candidates, attempting to exchange or actually exchanging or passing information and materials relevant to an ongoing examination, impersonation at examinations, the use of handsets/mobile phones to relate materials relevant to the examination, collusion and swapping of answer scripts, giraffesideways or forward glance at fellow students' answer scripts, changing of examination grades in return for material gains and changing of examination grades because of relationship (Wali, 2007).

In the light of the above, many scholars and educationalists have suggested strategies for curbing examination malpractice in schools and other areas where an examination is used as a yardstick for determining progress or otherwise. Wali (2007) has identified the following strategies as panacea to examination malpractice: removal of emphasis on certification, strict adherence to laws, right attitude to work, provision of adequate facilities, adherence to curriculum content, re-introduction of moral and religious studies or instruction, involvement of students in administration of schools, lectures, seminars, film strips and enlightenment campaigns in schools, etc.

In the same vein in his study on evolving innovative strategies for curbing examination malpractice in tertiary institutions in Nigeria, Onwuzo (2014) identified inculcating the right values and ethics in children, organizing seminars for students on how to study effectively by guidance counselors, reflecting examination codes and conduct on students' handbook, enactment of law on examination malpractice with inbuilt sanction to punish defaulters, provision of adequate infrastructure with closed circuit camera (CCC), adoption of online examination, and adoption of conference marking of scripts among others as strategies for curbing examination malpractice. Egbo (2015) investigated counseling strategies for curbing examination malpractices in secondary schools in Enugu State, Nigeria. The descriptive survey design and three research questions were used in the study. The sample of the study was made up of principals, PTA secretaries, teachers and counsellor all totaling 335 respondents drawn with the stratified random sampling technique. The method of data collection was a questionnaire containing 27 items. Data were analyzed with mean ratings. The study revealed the following as strategies for curbing examination malpractice: personal/social counselling strategies (Developing warm relationship with students, praising students' academic effort, showing affection and heartfelt concern to students, mandating students to declare through signed undertakings or sworn affidavits, keeping appropriate records of students' enrolment, giving awards for termly performances to students, etc.), educational counselling strategies (exposing students to quiz and reading competition, provision of counselling periods, monitoring of students classroom progress, organizing extra-moral classes, etc.).

In a related study, Obidoa, Onyechi, and Okere (2013) investigated examination malpractice and control in public secondary schools in Anambra State, Nigeria: Implication for the counsellor. The result of the study indicated that less emphasis on paper qualification, adequate equipment of schools, recruitment of qualified teachers, paying teachers adequately, good coverage of school syllabus, expulsion of erring students and teachers, value re-orientation of the society, reducing strikes through improved school administration, etc., are measures capable of controlling examination malpractice among students in secondary schools.

Esrom (2013) carried out a study on curbing examination malpractice in schools: Participative advocacy. The study identified sound educational policy, only formally registered sit for examination, thumb print in registration forms, frequent unannounced visits to examination body officials during examination days, appointment of supervisors of proven integrity and who are independent of the examination centre, prohibition of the use of electronic devices including cellular phones and papers, etc. as ways of curbing examination malpractice. 


\section{Statement of the Problem}

Examination malpractice has become a hydra-headed monster in the Nigerian educational system and has reduced the quality of the degrees and certificates awarded by the Universities in the country. The problem of this study was to find strategies for curbing examination malpractice in higher institutions in Rivers State.

\section{Methodology}

The study adopted the descriptive research design. The population of the study comprised all lecturers in higher institutions in Rivers State. The sample of the study consisted of 250 lecturers selected with the stratified random sampling technique. However, 215 lecturers fully filled and returned their questionnaire. The instrument for data collection was a questionnaire titled "Strategies for Curbing Examination Malpractice Questionnaire (SCEMQ)". The SCEMQ was divided into two sections: Section A consisted of demographic data such as sex, the length of services, rank, and faculty. Section B comprised 12 items designed to elicit responses from teachers on strategies for curbing examination malpractice. The Cronbach alpha method was used in establishing the reliability of SCEMQ. The reliability coefficient was found to be $\mathrm{r}=0.82$. Mean and the standard deviation was used to answering the research questions, while the hypotheses were tested with the independent t-test and analysis of variance (ANOVA) at 0.05 level of significance.

\section{Research Questions}

The following research questions guided the study:

- What are the strategies for curbing examination malpractice as measured by mean ratings of lecturers in higher institutions in Rivers State based on gender?

- What are the strategies for curbing examination malpractice as measured by the mean rating of lecturers in higher institutions in Rivers State based on length of service?

- What are the strategies for curbing examination malpractice as measured by mean ratings of lecturers in higher institutions in Rivers State based on rank?

- What are the strategies for curbing examination malpractice as measured by the mean rating of lecturers in higher institutions in Rivers State based on faculties?

\subsection{Hypotheses}

The following hypotheses were formulated to guide the study:

- There is no significant difference in the mean ratings of lecturers on examination malpractice based on gender.

- There is no significant difference in the mean ratings of lecturers on examination malpractice based on length of service.

- There is no significant difference in the mean ratings of lecturers in examination malpractice based on rank.

- There is no significant difference in the mean ratings of lecturers on examination malpractice based on faculty.

\subsection{Data Presentation}

\subsubsection{Research Question One}

What are the strategies for curbing examination malpractice as measured by the mean ratings of lecturers in higher institutions in Rivers State based on gender?

\begin{tabular}{|c|c|c|c|c|c|c|c|c|c|}
\hline S/ N & Statement/ Item & \multicolumn{3}{|c|}{ Male Lecturers } & \multicolumn{3}{|c|}{ Female Lecturers } \\
\cline { 3 - 9 } & $\mathrm{N}$ & $\bar{X}$ & $\mathrm{SD}$ & $\mathrm{Cm}$ & $\mathrm{N}$ & $\bar{X}$ & $\mathrm{SD}$ & $\mathrm{Cm}$ \\
\hline 1 & $\begin{array}{c}\text { Re-orientating students on examination } \\
\text { malpractice }\end{array}$ & 120 & 2.94 & 0.91 & 2.5 & 95 & 2.89 & 0.85 & 2.5 \\
\hline 2 & $\begin{array}{c}\text { Ensuring that examination questions are } \\
\text { adequately secured }\end{array}$ & 120 & 2.84 & 0.82 & 2.5 & 95 & 2.87 & 0.83 & 2.5 \\
\hline 3 & $\begin{array}{c}\text { Providing enough personnel or invigilation of } \\
\text { examination }\end{array}$ & 120 & 2.91 & 0.87 & 2.5 & 95 & 2.94 & 0.91 & 2.5 \\
\hline 4 & $\begin{array}{c}\text { Displaying fliers on the penalties of } \\
\text { examination security breach in the } \\
\text { Universities }\end{array}$ & 120 & 2.81 & 0.79 & 2.5 & 95 & 2.84 & 0.81 & 2.5 \\
\hline 5 & $\begin{array}{c}\text { Ensuring that examination questions are } \\
\text { within average difficulty level of students }\end{array}$ & 120 & 3.01 & 0.98 & 2.5 & 95 & 2.99 & 0.95 & 2.5 \\
\hline 6 & $\begin{array}{c}\text { Providing enough security at the examination } \\
\text { halls to prevent impersonation and } \\
\text { unauthorized persons }\end{array}$ & 120 & 2.98 & 0.94 & 2.5 & 95 & 3.01 & 0.98 & 2.5 \\
\hline 7 & Appending signatures on all the scripts used & 120 & 2.96 & 0.92 & 2.5 & 95 & 2.98 & 0.94 & 2.5 \\
\hline
\end{tabular}




\begin{tabular}{|c|c|c|c|c|c|c|c|c|c|}
\hline S/ N & Statement/ Item & \multicolumn{3}{|c|}{ Male Lecturers } & \multicolumn{3}{c|}{ Female Lecturers } \\
\cline { 3 - 8 } & & $\mathrm{N}$ & $\bar{X}$ & $\mathrm{SD}$ & $\mathrm{Cm}$ & $\mathrm{N}$ & $\bar{X}$ & $\mathrm{SD}$ & $\mathrm{Cm}$ \\
\hline 8 & $\begin{array}{c}\text { Prohibiting all electronic devices (GSM, } \\
\text { pagers) at examination halls }\end{array}$ & 120 & 3.06 & 1.02 & 2.5 & 95 & 3.02 & 0.99 & 2.5 \\
\hline 9 & $\begin{array}{c}\text { Adequate spacing of students to prevent } \\
\text { them from giraffe }\end{array}$ & 120 & 2.99 & 0.96 & 2.5 & 95 & 2.96 & 0.93 & 2.5 \\
\hline 10 & $\begin{array}{c}\text { Ensuring that prepared materials are not } \\
\text { brought and used in the examination halls }\end{array}$ & 120 & 3.02 & 0.99 & 2.5 & 95 & 3.01 & 0.97 & 2.5 \\
\hline 11 & $\begin{array}{c}\text { Ensuring that examination halls are } \\
\text { conducive }\end{array}$ & 120 & 2.88 & 0.84 & 2.5 & 95 & 2.97 & 0.94 & 2.5 \\
\hline 12 & Effective utilization of counselling units & 120 & 2.68 & 0.65 & 2.5 & 95 & 2.79 & 0.76 & 2.5 \\
\hline & Grand Mean & 120 & 2.92 & 0.89 & 2.5 & 95 & 0.91 & 0.91 & 2.5 \\
\hline
\end{tabular}

Table 1: Strategies for Curbing Examination Malpractice among Lecturers Based on Their Gender

Table 1 shows the strategies for curbing examination malpractice among lecturers in higher institutions in Rivers State based on gender. A close observation of Table 1 shows that the strategies identified in the study for curbing examination malpractice are accepted by male and female lecturers in higher institutions in Rivers State. This is because the mean ratings of these items are greater than criterion mean (2.5).

\subsubsection{Research Question Two}

What are the strategies for curbing examination malpractice as measured by the mean rating of lecturers in higher institutions in Rivers State based on length of service?

\begin{tabular}{|c|c|c|c|c|c|c|c|c|c|}
\hline \multirow[t]{2}{*}{$\mathbf{S} / \mathbf{N}$} & \multirow[t]{2}{*}{ Statement/ Item } & \multicolumn{4}{|c|}{$\begin{array}{c}\text { Lecturers with Many Years of } \\
\text { Service }\end{array}$} & \multicolumn{4}{|c|}{$\begin{array}{c}\text { Lecturers with Few Years o } \\
\text { Service }\end{array}$} \\
\hline & & $\mathrm{N}$ & $\bar{X}$ & SD & $\mathrm{Cm}$ & $\mathrm{N}$ & $\bar{X}$ & SD & $\mathrm{Cm}$ \\
\hline 1 & $\begin{array}{c}\text { Re-orientating students on examination } \\
\text { malpractice }\end{array}$ & 140 & 3.06 & 1.03 & 2.5 & 75 & 2.98 & 0.94 & 2.5 \\
\hline 2 & $\begin{array}{l}\text { Ensuring that examination questions are } \\
\text { adequately secured }\end{array}$ & 140 & 2.98 & 0.95 & 2.5 & 75 & 2.89 & 0.85 & 2.5 \\
\hline 3 & $\begin{array}{c}\text { Providing enough personnel or } \\
\text { invigilation of examination }\end{array}$ & 140 & 2.94 & 0.91 & 2.5 & 75 & 2.94 & 0.91 & 2.5 \\
\hline 4 & $\begin{array}{l}\text { Displaying fliers on the penalties of } \\
\text { examination security breach in the } \\
\text { Universities }\end{array}$ & 140 & 2.96 & 0.93 & 2.5 & 75 & 2.92 & 0.87 & 2.5 \\
\hline 5 & $\begin{array}{l}\text { Ensuring that examination questions are } \\
\text { within average difficulty level of students }\end{array}$ & 140 & 2.92 & 0.89 & 2.5 & 75 & 2.88 & 0.85 & 2.5 \\
\hline 6 & $\begin{array}{c}\text { Providing enough security at the } \\
\text { examination halls to prevent } \\
\text { impersonation and unauthorized } \\
\text { persons }\end{array}$ & 140 & 2.99 & 0.96 & 2.5 & 75 & 2.97 & 0.94 & 2.5 \\
\hline 7 & $\begin{array}{c}\text { Appending signatures on all the scripts } \\
\text { used }\end{array}$ & 140 & 2.87 & 0.84 & 2.5 & 75 & 2.93 & 0.89 & 2.5 \\
\hline 8 & $\begin{array}{l}\text { Prohibiting all electronic devices (GSM, } \\
\text { pagers) at examination halls }\end{array}$ & 140 & 2.99 & 0.95 & 2.5 & 75 & 3.01 & 0.97 & 2.5 \\
\hline 9 & $\begin{array}{l}\text { Adequate spacing of students to prevent } \\
\text { them from giraffe }\end{array}$ & 140 & 3.01 & 0.98 & 2.5 & 75 & 2.98 & 0.95 & 2.5 \\
\hline 10 & $\begin{array}{l}\text { Ensuring that prepared materials are not } \\
\text { brought and used in the examination } \\
\text { halls }\end{array}$ & 140 & 2.98 & 0.94 & 2.5 & 75 & 2.94 & 0.91 & 2.5 \\
\hline 11 & $\begin{array}{l}\text { Ensuring that examination halls are } \\
\text { conducive }\end{array}$ & 140 & 2.91 & 0.86 & 2.5 & 75 & 3.00 & 0.95 & 2.5 \\
\hline 12 & Effective utilization of counselling units & 140 & 2.74 & 0.71 & 2.5 & 75 & 2.64 & 0.62 & 2.5 \\
\hline & Grand Mean & 140 & 2.95 & 0.91 & 2.5 & 75 & 2.92 & 0.88 & 2.5 \\
\hline
\end{tabular}

Table 2: Strategies for Curbing Examination Malpractice among Lecturers Based on Their Length of Service 
Table 2 shows the strategies for curbing examination malpractice among lecturers in higher institutions in Rivers State based on their length of service. Lecturers with many years of service indicated that re-orienting students on examination are the commonest strategies for curbing examination malpractice $(\bar{x}=3.06)$. This is followed by an adequate spacing of students to prevent them from giraffe $(\bar{x}=3.01)$. The strategy for curbing examination malpractice with the least mean based on the responses of lecturers with many years of service is adhering strictly to the duration of the examination $(\bar{x}=2.74)$. On the other hand, lecturers with few years of service indicated that prohibiting all electronic devices (G.S.M, pagers etc) at examination halls $(\bar{x}=3.01)$. This is followed by ensuring that the examination hall is conducive $(\bar{x}=3.00)$. The strategy for curbing examination malpractice with the least mean based on the responses of lecturers with few years of service is adhering strictly to the duration of the examination $(\bar{x}=2.64)$. The grand mean $(2.95)$ and $(2.92)$ reveals that the strategies for curbing examination malpractice identified in the study are accepted by both categories of lecturers while the standard deviation reveals the extent of agreement of the lecturers on the strategies identified in the study for curbing examination malpractice in a higher institution in Rivers State.

\subsubsection{Research Question Three}

What are the strategies for curbing examination malpractice as measured by mean ratings of lecturers in higher institutions in Rivers State based on their rank?

\begin{tabular}{|c|c|c|c|c|c|c|c|c|c|c|c|c|c|}
\hline \multirow[t]{2}{*}{$\mathbf{S} / \mathbf{N}$} & \multirow[t]{2}{*}{ Statement/ Item } & \multicolumn{4}{|c|}{ Lectures 1 and Below } & \multicolumn{4}{|c|}{$\begin{array}{c}\text { Senior Lecturers and } \\
\text { Readers }\end{array}$} & \multicolumn{4}{|c|}{ Professors } \\
\hline & & $\mathrm{N}$ & $\bar{X}$ & SD & $\mathrm{Cm}$ & $\mathrm{N}$ & $\bar{X}$ & $\mathrm{SD}$ & $\mathrm{Cm}$ & $\mathrm{N}$ & $\bar{X}$ & SD & $\mathrm{Cm}$ \\
\hline 1 & $\begin{array}{l}\text { Re-orientating } \\
\text { students on } \\
\text { examination } \\
\text { malpractice }\end{array}$ & 109 & 2.94 & 0.91 & 2.5 & 92 & 2.98 & 0.95 & 2.5 & 14 & 3.02 & 1.01 & 2.5 \\
\hline 2 & $\begin{array}{l}\text { Ensuring that } \\
\text { examination } \\
\text { questions are } \\
\text { adequately } \\
\text { secured }\end{array}$ & 109 & 2.96 & 0.92 & 2.5 & 92 & 2.99 & 0.96 & 2.5 & 14 & 2.97 & 0.94 & 2.5 \\
\hline 3 & $\begin{array}{l}\text { Providing enough } \\
\text { personnel or } \\
\text { invigilation of } \\
\text { examination } \\
\end{array}$ & 109 & 2.91 & 0.87 & 2.5 & 92 & 2.94 & 0.91 & 2.5 & 14 & 2.99 & 0.96 & 2.5 \\
\hline 4 & $\begin{array}{l}\text { Displaying fliers } \\
\text { on the penalties of } \\
\text { examination } \\
\text { security breach in } \\
\text { the Universities }\end{array}$ & 109 & 2.87 & 0.83 & 2.5 & 92 & 2.92 & 0.87 & 2.5 & 14 & 2.96 & 0.93 & 2.5 \\
\hline 5 & $\begin{array}{c}\text { Ensuring that } \\
\text { examination } \\
\text { questions are } \\
\text { within average } \\
\text { difficulty level of } \\
\text { students }\end{array}$ & 109 & 2.85 & 0.81 & 2.5 & 92 & 2.96 & 0.92 & 2.5 & 14 & 2.95 & 0.91 & 2.5 \\
\hline 6 & $\begin{array}{l}\text { Providing enough } \\
\text { security at the } \\
\text { examination halls } \\
\text { to prevent } \\
\text { impersonation } \\
\text { and unauthorized } \\
\text { persons }\end{array}$ & 109 & 2.92 & 0.89 & 2.5 & 92 & 2.91 & 0.88 & 2.5 & 14 & 2.94 & 0.91 & 2.5 \\
\hline 7 & $\begin{array}{l}\text { Appending } \\
\text { signatures on all } \\
\text { the scripts used }\end{array}$ & 109 & 2.89 & 0.85 & 2.5 & 92 & 2.90 & 0.87 & 2.5 & 14 & 2.97 & 0.94 & 2.5 \\
\hline
\end{tabular}




\begin{tabular}{|c|c|c|c|c|c|c|c|c|c|c|c|c|c|}
\hline \multirow[t]{2}{*}{$\mathbf{S} / \mathbf{N}$} & \multirow[t]{2}{*}{ Statement/ Item } & \multicolumn{5}{|c|}{ Lectures 1 and Below } & \multicolumn{5}{|c|}{ Senior Lecturers and Readers } & \multicolumn{2}{|c|}{ Professors } \\
\hline & & $\mathrm{N}$ & $\bar{X}$ & SD & $\mathrm{Cm}$ & $\mathrm{N}$ & $\bar{X}$ & $\mathrm{SD}$ & $\mathrm{Cm}$ & $\mathrm{N}$ & $\bar{X}$ & SD & $\mathrm{Cm}$ \\
\hline 8 & $\begin{array}{c}\text { Prohibiting all } \\
\text { electronic devices } \\
\text { (GSM, pagers) at } \\
\text { examination halls }\end{array}$ & 109 & 2.97 & 0.94 & 2.5 & 92 & 2.00 & 0.99 & 2.5 & 14 & 3.01 & 0.99 & 2.5 \\
\hline 9 & $\begin{array}{l}\text { Adequate spacing } \\
\text { of students to } \\
\text { prevent them } \\
\text { from giraffe }\end{array}$ & 109 & 2.91 & 0.88 & 2.5 & 92 & 2.96 & 0.92 & 2.5 & 14 & 2.98 & 0.95 & 2.5 \\
\hline 10 & $\begin{array}{c}\text { Ensuring that } \\
\text { prepared } \\
\text { materials are not } \\
\text { brought and used } \\
\text { in the } \\
\text { examination halls }\end{array}$ & 109 & 2.93 & 0.89 & 2.5 & 92 & 2.95 & 0.91 & 2.5 & 14 & 3.01 & 0.98 & 2.5 \\
\hline 11 & $\begin{array}{l}\text { Ensuring that } \\
\text { examination halls } \\
\text { are conducive }\end{array}$ & 109 & 2.95 & 0.91 & 2.5 & 92 & 2.98 & 0.95 & 2.5 & 14 & 3.00 & 0.97 & 2.5 \\
\hline 12 & $\begin{array}{c}\text { Effective } \\
\text { utilization of } \\
\text { counselling units }\end{array}$ & 109 & 2.74 & 0.71 & 2.5 & 92 & 2.78 & 0.74 & 2.5 & 14 & 2.82 & 0.78 & 2.5 \\
\hline & Grand Mean & 109 & 2.90 & 0.86 & 2.5 & 92 & 2.94 & 0.91 & 2.5 & 14 & 2.97 & 0.94 & 2.5 \\
\hline
\end{tabular}

Table 3: Strategies for Curbing Examination Malpractice among Lecturers Based on Their Rank

Table 3 shows the strategies for curbing examination malpractice among lecturers in higher institutions in Rivers State based on their rank. A close observation of Table 3 indicated that the strategies identified in the study for curbing examination malpractice are accepted by the lecturers irrespective of their rank. This is because the mean ratings for each of the item and the grand mean score for each category of lecturers are greater than the criterion mean (2.5). The result of this research question is that the strategies identified in this study are some of the strategies for curbing examination malpractice in higher institutions in Rivers State.

4.2.4. Research Question Four

What are the strategies for curbing examination malpractice as measured by the mean rating of lecturers in higher institutions in Rivers State based on the faculties?

\begin{tabular}{|c|c|c|c|c|c|c|c|c|c|c|c|c|c|}
\hline \multirow[t]{2}{*}{$\mathbf{S} / \mathbf{N}$} & \multirow[t]{2}{*}{ Statement/ Item } & \multicolumn{4}{|c|}{$\begin{array}{c}\text { Lecturers from Faculty } \\
\text { of Science }\end{array}$} & \multicolumn{4}{|c|}{$\begin{array}{c}\text { Lecturers from Faculty } \\
\text { of Education }\end{array}$} & \multicolumn{4}{|c|}{$\begin{array}{c}\text { Lecturers from Faculty of } \\
\text { Humanities }\end{array}$} \\
\hline & & $\mathrm{N}$ & $\overline{\boldsymbol{X}}$ & SD & $\mathrm{Cm}$ & $\mathrm{N}$ & $\overline{\boldsymbol{X}}$ & SD & $\mathrm{Cm}$ & $\mathrm{N}$ & $\bar{X}$ & SD & $\mathrm{Cm}$ \\
\hline 1 & $\begin{array}{l}\text { Re-orientating students on } \\
\text { examination malpractice }\end{array}$ & 70 & 2.89 & 0.85 & 2.5 & 78 & 3.04 & 1.02 & 2.5 & 67 & 2.87 & 0.84 & 2.5 \\
\hline 2 & $\begin{array}{l}\text { Ensuring that examination } \\
\text { questions are adequately } \\
\text { secured }\end{array}$ & 70 & 2.94 & 0.91 & 2.5 & 78 & 2.91 & 0.87 & 2.5 & 67 & 2.85 & 0.81 & 2.5 \\
\hline 3 & $\begin{array}{l}\text { Providing enough } \\
\text { personnel or invigilation } \\
\text { of examination }\end{array}$ & 70 & 2.90 & 0.86 & 2.5 & 78 & 2.89 & 0.85 & 2.5 & 67 & 2.91 & 0.87 & 2.5 \\
\hline 4 & $\begin{array}{l}\text { Displaying fliers on the } \\
\text { penalties of examination } \\
\text { security breach in the } \\
\text { Universities }\end{array}$ & 70 & 2.91 & 0.87 & 2.5 & 78 & 2.85 & 0.81 & 2.5 & 67 & 2.94 & 0.91 & 2.5 \\
\hline
\end{tabular}




\begin{tabular}{|c|c|c|c|c|c|c|c|c|c|c|c|c|c|}
\hline \multirow[t]{2}{*}{$\mathbf{S} / \mathbf{N}$} & \multirow[t]{2}{*}{ Statement/ Item } & \multicolumn{4}{|c|}{$\begin{array}{l}\text { Lecturers from Faculty } \\
\text { of Science }\end{array}$} & \multicolumn{4}{|c|}{$\begin{array}{l}\text { Lecturers from Faculty } \\
\text { of Education }\end{array}$} & \multicolumn{4}{|c|}{$\begin{array}{c}\text { Lecturers from Faculty of } \\
\text { Humanities }\end{array}$} \\
\hline & & $\mathrm{N}$ & $\bar{X}$ & SD & $\mathrm{Cm}$ & $\mathrm{N}$ & $\bar{X}$ & SD & $\mathrm{Cm}$ & $\mathrm{N}$ & $\overline{\bar{X}}$ & SD & $\mathrm{Cm}$ \\
\hline 5 & $\begin{array}{l}\text { Ensuring that examination } \\
\text { questions are within } \\
\text { average difficulty level of } \\
\text { students }\end{array}$ & 70 & 2.89 & 0.84 & 2.5 & 78 & 2.92 & 0.88 & 2.5 & 67 & 2.89 & 0.85 & 2.5 \\
\hline 6 & $\begin{array}{l}\text { Providing enough security } \\
\text { at the examination halls to } \\
\text { prevent impersonation } \\
\text { and unauthorized persons }\end{array}$ & 70 & 2.88 & 0.85 & 2.5 & 78 & 2.90 & 0.86 & 2.5 & 67 & 2.86 & 0.83 & 2.5 \\
\hline 7 & $\begin{array}{l}\text { Appending signatures on } \\
\text { all the scripts used }\end{array}$ & 70 & 2.95 & 0.91 & 2.5 & 78 & 2.93 & 0.89 & 2.5 & 67 & 2.92 & 0.88 & 2.5 \\
\hline 8 & $\begin{array}{l}\text { Prohibiting all electronic } \\
\text { devices (GSM, pagers) at } \\
\text { examination halls }\end{array}$ & 70 & 2.91 & 0.87 & 2.5 & 78 & 2.96 & 0.93 & 2.5 & 67 & 2.91 & 0.87 & 2.5 \\
\hline 9 & $\begin{array}{l}\text { Adequate spacing of } \\
\text { students to prevent them } \\
\text { from giraffe }\end{array}$ & 70 & 2.98 & 0.96 & 2.5 & 78 & 2.90 & 0.86 & 2.5 & 67 & 2.82 & 0.78 & 2.5 \\
\hline 10 & $\begin{array}{c}\text { Ensuring that prepared } \\
\text { materials are not brought } \\
\text { and used in the } \\
\text { examination } \\
\text { halls } \\
\end{array}$ & 70 & 2.93 & 0.89 & 2.5 & 78 & 2.94 & 0.91 & 2.5 & 67 & 2.89 & 0.85 & 2.5 \\
\hline 11 & $\begin{array}{l}\text { Ensuring that examination } \\
\text { halls are conducive }\end{array}$ & 70 & 2.97 & 0.94 & 2.5 & 78 & 2.98 & 0.95 & 2.5 & 67 & 2.88 & 0.84 & 2.5 \\
\hline 12 & $\begin{array}{c}\text { Effective utilization of } \\
\text { counselling units } \\
\text { Grand Mean }\end{array}$ & $\begin{array}{l}70 \\
70\end{array}$ & $\begin{array}{l}2.66 \\
2.90\end{array}$ & $\begin{array}{l}0.63 \\
0.86\end{array}$ & $\frac{2.5}{2.5}$ & $\begin{array}{r}78 \\
78\end{array}$ & $\frac{2.69}{2.91}$ & $\begin{array}{l}0.65 \\
0.87\end{array}$ & $\begin{array}{l}2.5 \\
2.5\end{array}$ & $\begin{array}{l}67 \\
67\end{array}$ & $\begin{array}{l}2.65 \\
2.87\end{array}$ & $\begin{array}{l}0.61 \\
0.83\end{array}$ & $\begin{array}{l}2.5 \\
2.5\end{array}$ \\
\hline
\end{tabular}

Table 4: Strategies for Curbing Examination Malpractice among Lecturers Based on Their Faculty

Table 4 indicated the strategies for curbing examination malpractice among lecturers in higher institutions in Rivers State based on their faculties. A close observation of Table reveals that the strategies identified in the study for curbing examination malpractice are accepted by the lecturers irrespective of their faculties. The mean ratings of the lecturers based on their faculties on each of strategies are greater than the criterion mean (2.5). Also, the grand mean of the responses of the lecturers is greater than the criterion mean (2.5). The result of this research question is that the strategies for curbing examination malpractice identified in this study are accepted by the lecturers.

\subsection{Hypothesis 1}

There is no significant difference in the mean rating of lectures on strategies for curbing examination malpractice based on gender.

\begin{tabular}{|c|c|c|c|c|c|c|c|c|}
\hline Gender & $\mathbf{N}$ & $\overline{\boldsymbol{X}}$ & SD & Df & $\begin{array}{l}\text { Standard } \\
\text { Error }\end{array}$ & $\begin{array}{l}\text { Cal. t- } \\
\text { value }\end{array}$ & $\begin{array}{l}\text { Crit. t- } \\
\text { value }\end{array}$ & Remark \\
\hline Male lecturers & 120 & 2.92 & 0.89 & & & & & Not \\
\hline Female lecturers & 95 & 2.94 & 0.91 & 213 & 0.14 & 0.143 & 1.960 & significant \\
\hline
\end{tabular}

Table 5: T-Test Analysis of Mean Difference on Lecturers' Ratings Based on Their Gender

Table 5 shows that the degree of freedom is 213 , the standard error is 0.14 , calculated t-value is 0.143 while critical tvalue is 1.960 at 0.05 level of significance. Since the calculated t-value (0.143) is less than the critical t-value (1.960) at 0.05 level of significance, the null hypothesis of no significant difference in the mean rating of lectures on the strategies for curbing examination malpractice in higher institutions in Rivers State based on gender is accepted. This means that the alternate 
hypothesis is rejected. The result of this hypothesis is that the mean rating of lectures on strategies for curbing examination malpractice in higher institutions in Rivers State does not significantly differ based on their gender.

\subsection{Hypothesis 2}

There is no significant difference in the mean rating of lectures on the strategies for curbing examination malpractice based on length of service.

\begin{tabular}{|c|c|c|c|c|c|c|c|c|}
\hline Length of Service & $\mathbf{N}$ & $\overline{\boldsymbol{X}}$ & SD & $\begin{array}{c}\text { Df } \\
\text { Standard } \\
\text { Error }\end{array}$ & Cal. t-value & Crit. t-value & Remark \\
\hline $\begin{array}{c}\text { Lecturers with many } \\
\text { years of service }\end{array}$ & 140 & 2.95 & 0.91 & & & & & \\
\hline $\begin{array}{c}\text { Lecturers with few } \\
\text { years of service }\end{array}$ & 75 & 2.92 & 0.88 & 21 & 0.13 & 0.231 & 1.960 & $\begin{array}{c}\text { Not } \\
\text { significant }\end{array}$ \\
\hline
\end{tabular}

Table 6: T-Test Analysis of Mean Difference on Lecturers' Ratings Based on Length of Service

Table 6 reveals that the degree of freedom is 213 , the standard error is 0.13 , calculated t-value is 0.231 while critical tvalue is 1.960 at 0.05 level of significance. Since the calculated t-value (0.231) is less than the critical t-value (1.960) at 0.05 level of significance, the null hypothesis of no significant difference in the mean ratings of lectures on the strategies for curbing examination malpractice in higher institutions in Rivers state based on length of service is accepted. The result of this hypothesis is that the mean ratings of lectures on the strategies for curbing examination malpractice in higher institutions in Rivers State do not significantly differ based on their length of service.

\subsection{Hypothesis 3}

There is no significant difference in the mean ratings of lectures on the strategies for curbing examination malpractice in higher institutions in Rivers State based on rank.

\begin{tabular}{|c|c|c|c|c|}
\hline $\begin{array}{c}\text { Source of } \\
\text { Variation }\end{array}$ & $\begin{array}{c}\text { Sum of Squares } \\
\text { (SS) }\end{array}$ & $\begin{array}{c}\text { Degree of } \\
\text { Freedom }\end{array}$ & $\begin{array}{c}\text { Mean Squares } \\
\text { (MS) }\end{array}$ & F-Ratio \\
\hline Between & 6.32 & $3-1=2$ & 3.16 & 2.59 \\
\hline Within & 259.68 & $215-3=212$ & 1.22 & \\
\hline Total & 266.00 & 214 & & \\
\hline
\end{tabular}

Table 7: ANOVA Analysis of Mean Ratings of Lecturers Based on Their Rank

Table 7 shows that the calculated F-ratio is 2.59 while the critical F-ratio is 3.04 at 0.05 level of significance. Since the calculated F-ratio (2.59) is less than the critical F-ratio (3.04) at 0.05 level of significance, the null hypothesis that the mean ratings of lecturers on the strategies for curbing examination malpractice in higher institutions in Rivers State do not significantly differ based on their rank.

\subsection{Hypothesis 4}

There is no significant difference in the mean ratings of lecturers on the strategies for curbing examination malpractice in higher institutions in Rivers State based on their faculty.

\begin{tabular}{|c|c|c|c|c|}
\hline $\begin{array}{c}\text { Source of } \\
\text { Variation }\end{array}$ & $\begin{array}{c}\text { Sum of Squares } \\
\text { (SS) }\end{array}$ & $\begin{array}{c}\text { Degree of } \\
\text { Freedom }\end{array}$ & $\begin{array}{c}\text { Mean Squares } \\
\text { (MS) }\end{array}$ & F-Ratio \\
\hline Between & 8.02 & $3-1=2$ & 4.01 & 2.95 \\
\hline Within & 288.96 & $215-3=212$ & 1.36 & \\
\hline Total & 296.98 & 214 & & \\
\hline
\end{tabular}

Table 8: ANOVA Analysis of Mean Ratings of Lecturers Based on Their Faculty

Table 8 shows that the calculated F-ratio is 2.95 while the critical F-ratio is 3.04 at 0.05 level of significance. Since the calculated F-ratio (2.95) is less than the critical F-ratio (3.04) at 0.05 level of significance, the null hypothesis that the mean ratings of lecturers on the strategies for curbing examination malpractice in higher institutions in Rivers State does not significantly differ based on their faculty.

\section{Discussion of Findings}

The finding of research question 1 (Table 1) shows that the mean ratings of lecturers on the strategies for curbing examination malpractice in higher institutions based on their gender in Rivers State does not significantly differ. However, 
when the differences in the mean ratings were subjected to $t$-test analysis, the obtained t-value (Table 5) was found not to be statistically significant at 0.05 level of probability. This result is due to the fact that both male and female lecturers accepted the strategies for curbing examination malpractice in higher institutions in Rivers State identified in this study. This finding is in agreement with Obidoa, Onyechi, and Okere (2013) that certain strategies are effective in controlling examination malpractice in public secondary schools.

The finding of research question 2 (Table 2) reveals that the mean ratings of lecturers on the strategies for curbing examination malpractice in higher institutions based on length of service in Rivers State does not differ. However, when the differences in the mean ratings were subjected to t-test analysis, the obtained t-value (Table 6) was found not to be statistically significant at 0.05 level of probability. This result is because both categories of lecturers indicated that the strategies for curbing examination malpractice in higher institutions in Rivers State identified in this study can be used to curb examination malpractice. The finding of this study is in agreement with Wali (2007) who identified similar strategies as the ones identified in this study as a panacea to examination malpractice.

The finding of research question 3 (Table 3) indicated that the mean ratings of lecturers on the strategies for curbing examination malpractice in higher institutions based on their rank in Rivers State is not significantly different. When the differences in the mean ratings were subjected to ANOVA analysis, the obtained F-value (Table 7) was found not to be statistically significant at 0.05 level of probability. The result is due to the fact that lecturers irrespective of their rank indicated that the strategies identified in this study can be used to curb examination malpractice. The finding of this study is in agreement with Onwuzo (2014) that certain strategies can be used to curb examination malpractice.

The finding of research question 4 (Table 4) reveals that the mean ratings of lecturers on the strategies for curbing examination malpractice in higher institutions based on their faculty in Rivers State is not significantly different. When the differences in the mean ratings were subjected to ANOVA analysis, the obtained F-value (Table 8) was found not to be statistically significant at 0.05 level of probability. The result is because the lecturers from the faculties used in the study indicated that the strategies for curbing examination malpractice in higher institutions in Rivers State can actually be used to curb examination malpractice. This result is in agreement with Egbo (2015) that certain strategies can be used in curbing examination malpractice.

\section{Recommendations}

Based on the findings or results of the study, the researchers gave the following recommendations:

- Information and Communication Technology should be utilized in monitoring examination in order to forestall examination malpractice in higher institutions in Rivers State.

- Re-orientation of students on the dangers of examination malpractice in higher institutions in Rivers State should be a continuous exercise.

- Mechanism to secure answer booklets, question papers and other important items involved in examination should be put in place in higher institutions in Rivers State.

- The current efforts to combat sorting among lecturers in higher institutions in Rivers State should be strengthened.

- Adequate security should be provided at examination halls during examinations to prevent unauthorized personnel from forcing their way into the examination halls or smuggle prepared materials into the examination halls.

- There should be training and re-training of lecturers in higher institutions on the conduct of examinations.

\section{References}

i. Anzene, S.J. (2014). Trends in examination malpractice in Nigerian educational system and its effects on the socioeconomic and political development of Nigeria. Asian Journal of Humanities and Social Sciences, 2(3).

ii. Asuru, V.A. (2004). Examination malpractice. Agenda for a change. Port Harcourt: Owas Haven Enterprises.

iii. Egbo, A.C. (2015). Counselling strategies for curbing examination malpractices in secondary schools in Enugu State, Nigeria. World Journal of Education 5(3).

iv. Esrom, T.J. (2013). Curbing examination malpractice in schools: Participative advocacy. JORIND 11(2).

v. Ezekiel-Hart, J. (2006). Examination malpractice and the quality of student enrolment in tertiary institutions. In Ebong, J.M., and Ezekiel-hart (Eds.). Contemporary Issues in Education. Port Harcourt: Eagle Lithograph Press.

vi. Obidoa, M.A., Onyechi, K.C. \& Okere, A.U. (2013). Examination malpractice and control in public secondary schools in Anambra State, Nigeria: Implication for the counsellor. Journal of Education and Practice 4(28).

vii. Onwuzo, O.G.U. (2014). Evolving innovative strategies for curbing examination malpractice in tertiary institutions in Nigeria. Multidisciplinary Journal of Research Development 22(1).

viii. Wali, W.I. (2007). A handbook of contemporary issues on education in Nigeria. Port Harcourt: Pearl Publishers. 